\title{
The Influence of Occult Infection With Hepatitis B Virus on Liver Histology and Response to Interferon Treatment in Chronic Hepatitis C Patients
}

Claudia da Silva, Neiva Sellan Lopes Gonçales, Josiane Silveira Felix Pereira, Cecília Amélia Fazio Escanhoela, Maria Helena Postal Pavan and Fernando Lopes Gonçales Junior
Group of Hepatitis' Studies, Department of Clinical Medical ,, Faculty of Medical Sciences of UNICAMP,Campinas/SP, Brazil

Occult hepatitis B virus (HBV) infections have been identified in patients with chronic hepatitis $\mathrm{C}$ virus (HCV) infection, although the clinical relevance of occult $\mathrm{HBV}$ infection remains controversial. We searched for serum HBV DNA in $106 \mathrm{HBsAg}$ negative/anti-HBc positive patients with chronic $\mathrm{HCV}$ infection and in 150 blood donors $\mathrm{HBsAg}$ negative/anti-HBc positive/anti-HCV negative (control group) by nested-PCR. HCV genotyping was done in 98 patients and percutaneous needle liver biopsies were performed in 59 patients. Fifty-two patients were treated for HCV infection with interferon alone $(n=4)$ or combined with ribavirin $(n=48)$ during one year. At the end and 24 weeks after stopping therapy, they were tested for HCV-RNA to evaluate the sustained virological response (SVR). Among the $106 \mathrm{HCV}$-positive patients, 15 (14\%) were HBV-DNA positive and among the $150 \mathrm{HCV}$-negative blood donors, 6 (4\%) were HBV-DNA positive. Liver biopsy gave a diagnosis of liver cirrhosis in $2 / 10(20 \%)$ of the HBV-DNA positive patients and in $6 / 49(12 \%)$ of the $\mathrm{HBV}$-DNA negative patients. The degree of liver fibrosis and portal inflammation was similar in HCV-infected patients HBV-DNA, irrespective of HBV-DNA status. SVR was obtained in $37.5 \%$ of the HBV-DNA positive patients and in $20.5 \%$ of the HBV-DNA negative patients; this difference was not significant. In conclusion, these data suggested that occult HBV infection, which occurs at a relatively high frequency among Brazilian HCV-infected patients, was not associated with more severe grades of inflammation, liver fibrosis or cirrhosis development and did not affect the SVR rates when the patients were treated with interferon or with interferon plus ribavirin.

Key Words: Occult HBV infection, chronic HCV infection, HBV-DNA, PCR, HCV genotype, interferon treatment.

Hepatitis B virus (HBV) is an important human pathogen that causes both acute disease and chronic infection. Studies based on serological assays for HBV have led to the concept that HBV is eliminated after the resolution of an acute infection [1], although a chronic carrier state [2-4], defined as being positive for hepatitis

Received on 11 August 2004; revised 07 December 2004.

Address for correspondence: Dr. Fernando Lopes Gonçales Junior, Grupo de Estudo das Hepatites-FCM-UNICAMP, Av: Romeu Tortima, 725, Cidade Universitária, Campinas, São Paulo, Brazil. CEP: 13083-885. Tel/fax:55-19-3788-7727

Email: flgj@uol.com.br

The Brazilian Journal of Infectious Diseases 2004;8(6):431-439 (C) 2004 by The Brazilian Journal of Infectious Diseases and Contexto Publishing. All rights reserved.
B surface antigen (HBsAg) for at least six months [5-7], has been reported to occur in about $5 \%$ of affected adults [8]. During acute and chronic $\mathrm{HBV}$ infections, antibodies against the core antigen of $\mathrm{HBV}$ (anti-HBc) are found together with $\mathrm{HBsAg}$, whereas in resolved infections they are accompanied by antibodies against HBsAg (anti$\mathrm{HBs}$ ). About 10-20\% of all individuals with hepatitis B have anti-HBc as the only marker of HBV infection [9]. In about $10 \%$ of these individuals HBV-DNA can be detected by a PCR assay $[9,10]$. HBV infection may also occur in HBsAg-negative patients who have serological markers of previous infection (anti-HBs) [11]. These HBV infections in patients who lack detectable $\mathrm{HBsAg}$ are called occult infections [11]; the serum HBVDNA levels are usually less than $10^{4}$ copies/mL [12]. 
Recently, very low levels of HBV-DNA have also been identified in the sera of patients with chronic hepatitis $\mathrm{C}$ virus (HCV) infection, even though there is no HBsAg in the serum $[11,13,14-18]$. It appears that this occult infection contributes to chronic liver damage and to the development of hepatocellular carcinoma [11,15,19-22]. Occult HBV infection can also be associated with a lack of response to interferon treatment in patients with chronic hepatitis C $[11,18]$. Recently, we used PCR to study the prevalence of occult HBV infection in serum samples of 106 patients with chronic $\mathrm{HCV}$ infection who were both $\mathrm{HBsAg}$ negative and anti-HBc positive. HBV-DNA was detected in 15 (14\%) of them [23].

We evaluated how occult HBV infection influences epidemiological, laboratorial, histological and therapeutic features of Brazilian HCV-infected patients.

\section{Material and Methods}

Between March 2000 and May 2002, we selected 106 patients who had been infected by HCV (anti$\mathrm{HCV}$ and HCV-RNA positive) and who were being followed-up at the University Hospital of UNICAMP. None of the patients had detectable HBsAg or were infected by human immunodeficiency virus (HIV). All of them had serum markers of previous HBV infection: all were anti-HBc positive and $56(53 \%)$ were also anti-HBs positive. In the first phase these selected patients were tested for HBV-DNA by an "in house" nested-polymerase chain reaction (nested-PCR) [23]. To estimate the viral load of the samples determined positive for HBV-DNA by "in house" PCR, a commercial test for HBV-DNA (HBV Monitor Roche, Roche Diagnostic Systems, Branchburg, NJ), with a lower detection limit of 1,000 copies/mL, was used.

Based on the nested-PCR results the patients were divided into two groups: one group was $\mathrm{HCV}$ positive/HBV DNA positive $(n=15)$ and the other was HCV positive/HBV DNA negative $(n=91)$. The $\mathrm{HCV}$ genotype was determined in the serum of 98 patients, before initiating specific therapy for HVC infection.
Percutaneous needle biopsies of the liver were made in 59/106 patients, in order to evaluate the degree of histological lesion. All liver biopsy specimens were fixed, paraffin embedded, and stained with hematoxylin-eosin safranin and Masson trichrome for histological and immunohistochemical examination. A numerical score was calculated for each liver biopsy specimen, both for grading necroinflammatory activity and for determining the degree of fibrosis. The patients were divided into three categories according to the histological findings: those with minimal or non-specific changes, those with mild-to-moderate chronic hepatitis, and those with severe chronic hepatitis, with features of cirrhosis. The stage of fibrosis was determined according to METAVIR score and varied from 0 to 4 (F0 = no fibrosis; $\mathrm{F} 1=$ portal fibrosis without septa; F2 = portal fibrosis with few septa; F3 = septal fibrosis, without cirrhosis; F4 = cirrhosis) $[11,24,25]$.

A control group to compare the epidemiological data was constituted of 150 blood donors who were HBsAg negative/ anti-HBc positive in blood bank screening. To identify occult HBV infection among these controls, we also tested these samples with "in house" nestedPCR [23], and we used a commercial test for HBVDNA (HBV Monitor Roche, Roche Diagnostic Systems, Branchburg, NJ) with a lower detection limit of 1,000 copies/mL to estimate the viral load of these positive samples.

Based on PCR results the controls were subdivided into: one group that was HCV negative/HBV-DNA positive $(n=6)$ and another group that was $\mathrm{HCV}$ negative/HBV-DNA negative $(n=144)$.

All the HCV-infected and control individuals were interviewed with a questionnaire to investigate risk factors to acquire these viruses. This questionnaire included questions about age, sex, sexual contacts, transfusions of blood or derivatives, use of illicit drugs by intravenous routes, tattooing, and acupuncture.

At the end of the study, 52 patients had completed the treatment for $\mathrm{HCV}$ infection, and they were followed up for 24 weeks after ending therapy. These patients were treated with interferon a-2a $3 \mathrm{MU}$ t.i.w, alone $(n=4)$ or combined with ribavirin $(1,000-1,200$ $\mathrm{mg} /$ daily) $(\mathrm{n}=48)$ during one year. During the entire 
follow-up period the ALT/AST levels were measured to evaluate the biochemical response. At the end of therapy, and 24 weeks later, the serum of these patients was tested for HVC-RNA. Patients who were HCVRNA negative 24 weeks after the end of therapy, were considered to have a sustained virological response (SVR). Virological testing was done in accordance with the ethical guidelines of the authors' institutions.

\section{Serum markers for HBV, HIV and HCV infection}

Serum HBsAg and anti-HBc were evaluated with commercial immunoenzymatic assays (Hepanostika HBsAg Uniform II and Hepanostika anti-HBc Uniform; Organon Teknika, Boxtel, Netherlands, respectively) and were tested for anti-HBs (AUSAB MEIA, Abbott Laboratories, North Chicago, IL), anti-HCV (antiHCV assay version 3.0; Abbott Murex, Dartford, UK), and anti-HIV (anti-HIV1.2.O assay; Abbott Murex,Dartford, UK). HCV infection was defined as the presence of anti-HCV antibodies and HCV-RNA (HCV-AMPLICOR, Roche Diagnostic Systems, Branchburg, NJ) in the serum. The HCV genotype was determined by a commercial assay (INNO LIPA Innogenetics, Belgium) before starting interferon therapy. All the assays were performed according to manufacturers instructions.

\section{Detection of Hepatitis B virus DNA in the serum}

The nested-PCR method for detection of HBV DNA was performed essentially as described previously by KANEKO et al [26,27]. A $10 \mathrm{~mL}$ aliquot of serum was pipetted into a $0.2 \mathrm{~mL}$ micro centrifuge tube. The serum was then incubated with $2.5 \mathrm{~mL}$ of $0.5 \mathrm{M} \mathrm{NaOH}$ at $37^{\circ} \mathrm{C}$ for 60 minutes. After incubation, the solution was brought to a neutral $\mathrm{pH}$ with $0.5 \mathrm{M} \mathrm{HCl}$, and the sample was used for PCR amplification of HBV DNA sequences. The samples were amplified in a $100 \mathrm{~mL}$ reaction volume containing 2.5 U of Taq polymerase (Bethesda Research Laboratories, Life Technologies Inc., Gaithersburg, Maryland), 200mM each of the four deoxyribonucleic triphosphates, $1 \mathrm{mM}$ of the primer pair (primers 1763 ' GCTTTGGGGCATGGACATTGACCCGTATAA3' and 2032R 5' CTGACTACTAATTCCCTGGATGCTGGGTCT3'), 50mM KCl, 10mM Tris- $\mathrm{HCl}$ (pH 8.3), and 1.5 $\mathrm{mM} \mathrm{MgCl}$. The amplification routine was: 25 cycles; 1.5 minutes at $94^{\circ} \mathrm{C}, 1.5$ minutes at $42^{\circ} \mathrm{C}$ and 3 minutes at $72^{\circ} \mathrm{C}$, in a DNA Thermal Cycler (Perkin Elmer Cetus, Foster City, Ca, USA). For reamplification, a $10 \mathrm{~mL}$ aliquot of the primary PCR reaction was amplified as described above, using primer pair (1778-E 5' GACGAATTCCATTGACCCGTATAAAGAATT$3^{\prime}$ and 2017R-B 5' ATGGGATCCCTGGATGCTGGGTCTTCCAAA3'). An aliquot of water was used as a negative control and serum from an HBV positive individual according to EIA quantified with the Amplicor HBV Monitor test (Roche Diagnostic Systems, Branchburg, NJ) (1.0 X $10^{2}$ copies $\left./ \mathrm{mL}\right)$ was used as a positive control. Serial dilutions were made in an HBsAg low-titer performance panel (PHA 105; Boston Biomedica, Inc., Boston, Mass), with which we determined the detection limit of our nested PCR as being $10^{2}$ copies $/ \mathrm{mL}$. Carryover contamination was prevented as described by KWOK\& HIGUCHI [28]. The final amplification product was mixed with bromphenol blue, eletrophoresed in a $2 \%$ agarose gel, visualized by UV fluorescence after staining with ethidium bromide, and photographed with Polaroid film. Samples were considered positive if they yielded at least two positive results from three amplifications. Samples were considered negative when there were two negative results in two different reactions.

\section{Statistical analysis}

The student's t-test and the Mann-Whitney test were used to analyze quantitative data. Fischer's exact test was used to analyze quantitative data and for comparing proportions [29]. All calculated $p$ values were two-tailed; a $\mathrm{p}$ value $<0.05$ was considered significant. 


\section{Results}

The demographic characteristics and risk factors for HCV infection are shown in Table 1. Among our $106 \mathrm{HCV}$-infected patients, 88 (83\%) were male and 18 (17\%) females. In the HBV-DNA positive group $11 / 88(12.5 \%)$ were men and 4/18 (22\%) women (p>0.05). The median age was $47.2 \pm 9.7$ years among $\mathrm{HCV}$ positive/HBV-DNA positive patients and was $46.4 \pm 9.3$ years among $\mathrm{HCV}$ positive/HBV-DNA negative patients ( $p>0.05$ ). Among the $150 \mathrm{HCV}$ negative blood donors, 101 (67\%) were male and 49 (33\%) were females. HBV-DNA was found in 4/101 (4\%) men and in $2 / 49(4 \%)$ women ( $>>0.05)$. The median age was $33.8 \pm 11.8$ years in the $\mathrm{HCV}$ negative/ HBV-DNA positive blood donors and was $39.8 \pm 10.8$ years in the $\mathrm{HCV}$ negative/HBV-DNA negative blood donors ( $p>0.05$ ). There was no significant association of sex or age and HBV-DNA in either group.

In the analysis of risk factors, among the $106 \mathrm{HCV}$ infected patients, 34 (32\%) were intravenous drug users (IVDU); 23 (21.7\%) had received blood transfusion, $20(18.9 \%)$ had surgery, 2 (1.9\%) reported unsafe sexual contact, 2 (1.9\%) reported more than 1 risk factor (tattoo and acupuncture), and 25/106 (23.6\%) denied risk factors. Among the $150 \mathrm{HCV}$-negative/anti$\mathrm{HBc}$ positive blood donors 8 (5.3\%) were IVDU; $17(11.3 \%)$ had received a blood transfusion, $1(0.7 \%)$ had surgeries, $46(30.7 \%)$ indicated sexual contact as a risk factor, $10(6.7 \%)$ reported more than 1 risk factor and $68(45.3 \%)$ denied any risk factors for HCV infection. No significant association was found between risk factors and $\mathrm{HBV}$-DNA presence.

Among the blood donors, 5.3\% were IVDU, while $32 \%$ of the HCV-positive group were IVDU $(\mathrm{p}<0.05)$. Unsafe sexual practice was reported by $1.9 \%$ of the $\mathrm{HCV}$-positive group and in $30.7 \%$ of the blood donors $(\mathrm{p}<0.05)$. When all sub-groups (HBV-DNA negative or positive) were compared, significant differences among risk groups were found for virus acquisition, mainly because there were more IVDU in the HCVpositive group, with or without occult HVB infection, when compared with the group of blood donors who were HBV-DNA negative (Table 1).
We were able to determine the HCV genotype in 98 $\mathrm{HCV}$-positive patients. Genotype 1 was encountered in $62 / 98(63 \%)$, genotype 2 in $1 / 98(1 \%)$, genotype 3 in $32 / 98(33 \%)$ and genotype 1 and 3 in 3/98 (3\%). The frequencies of the different $\mathrm{HCV}$ genotypes were similar in $\mathrm{HCV}$-positive patients with and without occult HBV infection ( $p>0.05$, Table 2).

Liver biopsies were taken from $59 \mathrm{HCV}$-positive patients. Among them 2 (3\%) presented minimal changes, $49(83 \%)$ had chronic hepatitis and $8(14 \%)$ had liver cirrhosis. Liver cirrhosis was diagnosed in $2 / 10$ (20\%) of the HBV-DNA positive patients and in 6/49 (12\%) of the HBV-DNA negative patients ( $>>0.05$ ). HBV-DNA presence was not significantly associated with more advanced histological lesions in the liver in HCVpositive patients ( $p>0.05$, Table 2 ). Liver fibrosis and portal inflammation were found at similar rates in HCVinfected patients with or without HBV-DNA positive in serum ( $p>0.05$, Table 3). Immunohistochemical staining was negative for $\mathrm{HBsAg}$ and $\mathrm{HBcAg}$ in all liver biopsies from $\mathrm{HCV}$ positive/HBV-DNA positive patients. Fiftytwo HCV-positive patients were treated with interferon $(n=4)$ or with a combination of interferon plus ribavirin ( $n$ $=48$ ) during 48 weeks. No significant differences were found in the rates of biochemical or virological responses in the HCV-infected patients with or without HBV-DNA in the sera ( $p>0.05$, Table 4$)$.

\section{Discussion}

Initially, we looked for occult HBV infection in $\mathrm{HBsAg}$ negative/anti-HBc positive individuals, with and without chronic $\mathrm{HCV}$ infection. This population of $\mathrm{HCV}$-infected patients and blood donors is representative of the general population in our region. We found that $14 \%$ of the $\mathrm{HCV}$-infected patients had detectable $\mathrm{HBV}$ genome in their serum. This prevalence was significantly higher than that found among HCVnegative individuals (4\%) [23]. The reasons for the disappearance of HBsAg and, in some cases, of all $\mathrm{HBV}$ markers, despite the persistence of $\mathrm{HBV}$ infection, are not completely understood. Some researchers consider that HBV could be present at very low levels, 
Table 1. Characteristics and risk factors in hepatitis $\mathrm{C}$ virus (HCV)-infected patients divided according to hepatitis $\mathrm{B}$ virus (HBV)-DNA positivity

\begin{tabular}{|c|c|c|c|c|c|c|c|c|c|c|c|c|}
\hline \multirow[t]{2}{*}{ Characteristic } & \multicolumn{6}{|c|}{$\mathrm{HCV}(+) /$ anti-HBc (+) } & \multicolumn{6}{|c|}{ HCV (-)/ anti-HBc (+) } \\
\hline & \multicolumn{2}{|c|}{$\begin{array}{c}\text { HBV-DNA }(+) \\
n=15\end{array}$} & \multicolumn{2}{|c|}{$\begin{array}{c}\text { HBV-DNA }(-) \\
n=91\end{array}$} & \multicolumn{2}{|c|}{$\begin{array}{c}\text { Total } \\
\mathrm{n}=106\end{array}$} & \multicolumn{2}{|c|}{$\begin{array}{c}\text { HBV-DNA }(+) \\
\mathrm{n}=6\end{array}$} & \multicolumn{2}{|c|}{$\begin{array}{c}\text { HBV-DNA (-) } \\
\mathrm{n}=144\end{array}$} & \multicolumn{2}{|c|}{$\begin{array}{c}\text { Total } \\
\mathrm{n}=150\end{array}$} \\
\hline Mean age (yr) & \multicolumn{2}{|c|}{$47.2 \pm 9.7$} & \multicolumn{2}{|c|}{$46.4 \pm 9.3$} & \multicolumn{2}{|c|}{$46.8 \pm 9.5$} & \multicolumn{2}{|c|}{$33.8 \pm 11.8$} & \multicolumn{2}{|c|}{$39.8 \pm 10.8$} & \multicolumn{2}{|c|}{$36.8 \pm 11.3$} \\
\hline $\operatorname{Sex}(M / F)$ & & $/ 4$ & & $7 / 14$ & & $/ 18$ & & $4 / 2$ & & $1 / 47$ & 101 & \\
\hline Risk Factors & $\mathbf{n}$ & $(\%)$ & $\mathbf{n}$ & $(\%)$ & $\mathbf{n}$ & $(\%)$ & $\mathbf{n}$ & $(\%)$ & $\mathbf{n}$ & $(\%)$ & $\mathbf{n}$ & $(\%)$ \\
\hline IVDU & $4 / 15$ & (26.7) & 30/91 & (33) & $34 / 106$ & (32) & $1 / 69$ & (16.7) & $7 / 144$ & $(4.9)$ & $8 / 150$ & (5.3) \\
\hline Transfusion & $3 / 15$ & (20) & 20/91 & (22) & $23 / 106$ & (21.7) & - & - & $17 / 144$ & $(11.8)$ & $17 / 150$ & (11.3) \\
\hline Surgery & $4 / 15$ & (26.7) & $16 / 91$ & $(17.6)$ & $20 / 106$ & (18.9) & - & - & $1 / 144$ & $(0.7)$ & $1 / 150$ & $(0.7)$ \\
\hline $\begin{array}{l}\text { Unsafe sexual } \\
\text { practices }\end{array}$ & - & - & $2 / 91$ & $(2.2)$ & $2 / 106$ & (1.9) & $1 / 6$ & $(16.7)$ & $45 / 144$ & $(31.2)$ & $46 / 150$ & (30.7) \\
\hline Not determined & $4 / 15$ & (26.6) & $21 / 91$ & (23) & $25 / 106$ & (23.6) & $4 / 6$ & $(66.6)$ & $64 / 144$ & $(44.5)$ & $68 / 150$ & $(45.3)$ \\
\hline Others* & - & - & $2 / 91$ & $(2.2)$ & $2 / 106$ & (1.9) & - & - & $10 / 144 * *$ & $=(6.9)$ & $10 / 150$ & (6.7) \\
\hline
\end{tabular}

*Tattoo/acupuncture. **Transfusion/Sexual. IVDU: Intravenous drug use. p $>0.05$ for comparison of HBV-DNA(+)/HBV-DNA(-) patients in both groups. $\mathrm{P}<0.05$ when all sub-groups (HBV-DNA negative or positive) are compared.

Table 2. Hepatitis $\mathrm{C}$ virus (HCV) genotypes and histological diagnosis in $\mathrm{HCV}$-positive patients, divided according to HBV-DNA positivity in the serum

\begin{tabular}{|c|c|c|c|c|}
\hline \multirow{2}{*}{$\begin{array}{l}\text { Variable } \\
\text { Genotype }\end{array}$} & \multicolumn{2}{|c|}{$\begin{array}{l}\text { HBV DNA (+) } \\
\text { n=14 }\end{array}$} & \multicolumn{2}{|c|}{$\begin{array}{l}\text { HBV DNA (-) } \\
n=84\end{array}$} \\
\hline & $\mathbf{n}$ & $(\%)$ & $\mathbf{n}$ & $(\%)$ \\
\hline 1 & 9 & (64) & 53 & $(63)$ \\
\hline 2 & - & - & 1 & $(1.2)$ \\
\hline 3 & 5 & (36) & 27 & $(32)$ \\
\hline \multirow[t]{2}{*}{$1+3$} & - & - & 3 & (3.6) \\
\hline & \multicolumn{2}{|c|}{$\begin{array}{l}\text { HBV DNA (+) } \\
n=10\end{array}$} & \multicolumn{2}{|c|}{$\begin{array}{l}\text { HBV DNA (-) } \\
n=49\end{array}$} \\
\hline Histological diagnosis & $\mathbf{n}$ & $(\%)$ & $\mathbf{n}$ & $(\%)$ \\
\hline Minimal changes & 1 & (10) & 1 & (2) \\
\hline Chronic hepatitis (mild/severe) & 7 & (70) & 42 & (86) \\
\hline Cirrhosis & 2 & (20) & 6 & (12.3) \\
\hline
\end{tabular}

$\mathrm{P}>0.05$ for comparison of patients HBV-DNA(+)/HBV-DNA(-). 
Table 3.Histopatological alterations observed in liver biopsies from 59 patients with chronic hepatitis C

\begin{tabular}{lcccc}
\hline Liver histology & \multicolumn{2}{c}{ HBV-DNA (+) } & \multicolumn{2}{c}{ HBV-DNA (-) } \\
Fibrosis & $\begin{array}{c}\text { n=49 } \\
\text { n }\end{array}$ & $(\%)$ & $\mathbf{n}$ & $(\%)$ \\
\hline No fibrosis (F0) & 1 & $(10)$ & 4 & $(8.2)$ \\
Portal fibrosis without septa (F1) & 2 & $(20)$ & 15 & $(31)$ \\
Portal fibrosis with few septa (F2) & 3 & $(30)$ & 15 & $(31)$ \\
Septal fibrosis without cirrhosis & 2 & $(20)$ & 9 & $(18)$ \\
Cirrhosis & 2 & $(20)$ & 6 & $(12)$ \\
\hline Portal inflammation & $\mathbf{n}$ & $(\boldsymbol{\%})$ & $\mathbf{n}$ & $(\%)$ \\
None & 1 & $(10)$ & - & - \\
Mild & 5 & $(50)$ & 27 & $(55)$ \\
Moderate & 4 & $(40)$ & 19 & $(39)$ \\
Severe & - & - & 3 & $(6)$ \\
\hline
\end{tabular}

HBV: Hepatitis B virus. $\mathrm{P}>0.05$ for comparison of patients $\mathrm{HBV}-\mathrm{DNA}(+) / \mathrm{HBV}-\mathrm{DNA}(-)$.

Table 4. Response to interferon treatment in patients with chronic hepatitis $\mathrm{C}$ virus infection, with and without occult hepatitis B virus (HBV) infection

\begin{tabular}{lcccc}
\hline Response to treatment & $\begin{array}{c}\text { HBV-DNA (+) } \\
\mathbf{n = 4 4} \\
\mathbf{n}\end{array}$ & $\mathbf{\%}$ & $\mathbf{n}$ & $\mathbf{\%}$ \\
\hline Sustained virological response & 3 & $(37)$ & 9 & $(21)$ \\
Biochemical response & 1 & $(12)$ & 11 & $(25)$ \\
Non-response & 4 & $(50)$ & 24 & $(55)$ \\
\hline
\end{tabular}

$\mathrm{P}>0.05$ for comparison of patients $\mathrm{HBV}-\mathrm{DNA}(+) / \mathrm{HBV}-\mathrm{DNA}(-)$.

undetectable by conventional serological assays. The HBsAg could elude detection by the polyclonal antibody used in conventional assays in the presence of HBsAg or HBsAg/anti-HBs immune complexes [30]. It is also possible that virions that are not transcriptionally active or replicating, quiescent or latent virions, are able to evade the surveillance of host immune cells [31]. Hepatocytes could be repeatedly re-infected by HBV virions, which could persist independently in peripheral blood mononuclear cells, or in other lymphoid tissues $[10,32]$. We found that
HBV-DNA persisted at low levels in patients with apparently resolved HBV infection. We utilized a highly sensitive in-house PCR test with a detection limit of 100 copies/mL [23]. The positive samples were tested afterwards with a commercial test that had a detection limit of 1,000 copies/mL, and all were negative. Thus, our HBV-DNA-positive patients, and the blood donors of the control group, had more than 100 and less than 1,000 copies/mL, which indicates that low levels of $\mathrm{HBV}$-DNA are generally present in the sera of patients with occult $\mathrm{HBV}$ infection. 
In co-infected patients, HBV and HCV may have a low rate of replication, due to mutual interference between these viruses [8,33-37). Some researchers believe that HCV has a strong suppressive effect on HVB replication [13,33,38-42], while others attribute to $\mathrm{HBV}$ the dominant role as an inhibitor of replication. [33 - 43]. It seems that inhibition of HBV replication by HCV is more common than the opposite [44].

Occult HBV infection in HCV-infected patients has been suggested as a possible co-factor, responsible for both impaired response to interferon therapy $[13,18]$ and more severe liver disease $[11,17,45,46]$.

In Italy, Cacciola et al., in a study of HCV-positive patients who were $\mathrm{HBs} \mathrm{Ag}$ negative/anti-HBc positive, were able to detect HBV-DNA in $46 \%$ of them. Liver cirrhosis was diagnosed in $33 \%$ of the $\mathrm{HCV}$-infected patients who were HBV-DNA positive and in $19 \%$ of the HBV-DNA negative HCV-infected patients [11]. They hypothesized that occult HBV infection could favor or accelerate the evolution to cirrhosis in HCVpositive patients $[11,40]$. Since cirrhosis is the most important risk factor for the development of hepatocellular carcinoma, a relation between HBV occult infection and this complication should be considered.

We found liver cirrhosis in $20 \%$ of the HBV-DNApositive patients and in $12 \%$ of the HBV-DNA negative patients. However, there was no significant difference between these two groups. Among our HCV-infected patients, the histopathological lesions in the liver were not more intense than in patients without occult HBV infection. Other researchers [35,46-48] also observed that occult $\mathrm{HBV}$ infection in $\mathrm{HCV}$-infected patients does not seem to be associated with more severe liver disease. On the other hand, some researchers indicated that anti-HBc (previous HBV infection), rather than occult HBV infection, is associated with a worse outcome in $\mathrm{HCV}$-infected patients $[35,46]$.

Differences among the populations, different sensitivities of the assays used to detect HBV-DNA, different types of specimen used to detect the presence of $\mathrm{HBV}$ (serum or liver) and different prevalences of HBV infection in the general population of various countries, could explain the conflicting results. We were not able to detect liver tissue markers (HBsAg and $\mathrm{HBcAg}$ ) in the HBV-DNA positive patients by immunoperoxidase staining. The same was observed in Italian patients [11]. We consider that this could be due to the very low HBV-DNA titers in the livers of the patients, the low intrinsic sensitivity of the immunohistochemical method, or because the HCVinfected patients with occult HBV infection had only residual replication outside of the liver.

Among oriental patients with occult HBV infection, it was observed that they are more frequently infected with HCV genotype 1b [13]. We did not find a significant difference in the frequencies of $\mathrm{HCV}$ genotypes in $\mathrm{HCV}$-infected patients with or without HBV-DNA. The same was observed for similar HCVpositive patients in Italy [46].

A reduced response to interferon therapy has been described in individuals with chronic hepatitis $\mathrm{C}$ and serological markers of a resolved $\mathrm{HBV}$ infection ( $\mathrm{HBsAg}$ negative/anti-HBc positive), perhaps due to an inapparent HBV co-infection in these patients [18]. More recently, some authors have observed that occult HBV infection correlates with a lack of response to interferon treatment in patients with chronic hepatitis $\mathrm{C}[11,18,45]$. Cacciola et al. detected a virological response in $21 \%$ and $42 \%$ of HCV-positive patients who had an occult infection with HBV or not, respectively [11]. We did not find a significant difference in the virological response of HCVpositive patients, with or without occult HBV infection (37.5\% and $20.5 \%$ respectively), when they were treated with interferon alone, or associated with ribavirin. The low levels of HBV-DNA in our patients did not interfere in the response to therapy. The same was observed in a recent study made in Taiwan with 110 patients who had chronic HCV infection. The prevalence of occult HBV infection did not parallel the severity of liver disease, and the sustained response to combination therapy against $\mathrm{HCV}$ was comparable between patients with or without occult HBV infection (38 versus 39\%). These researchers concluded that occult HBV infection had no clinical significance in chronic hepatitis C [47].

Finally, we emphasize the high prevalence of occult HBV infection (14\%) among our Brazilian patients with chronic hepatitis $\mathrm{C}$ who were HBsAg negative/ anti- 
$\mathrm{HBc}$ positive when compared with the prevalence observed in $\mathrm{HBs} \mathrm{Ag}$ negative/anti-HBc positive/HCV negative blood donors $(5.4 \%)$. We did not find an association among the risk factors to acquire both $\mathrm{B}$ and $\mathrm{C}$ viruses with higher rates of occult HBV infection. No significant association was found between more severe grades of liver fibrosis or cirrhosis in HCV-infected patients and HBV-DNA in sera. The SRV rates obtained with interferon therapy in $\mathrm{HCV}$-positive patients apparently were not affected by occult HBV infection. New studies should be made to determine if occult HBV infection, with low levels of HBV-DNA, can accelerate the natural course of chronic hepatitis $\mathrm{C}$ and influence the response to therapy.

\section{References}

1. Owiredu W. K. B. A., Kramvis A., Kew M. C. Hepatitis B virus DNA in serum of healthy black African adults positive for hepatitis B surface antibody alone: Possible association with recombination between genotypes $\mathrm{A}$ and D J Med Virol 2001;64:441-54.

2. Bahn A., Gerner P., Mariné U.,. et al. Detection of different viral strains of hepatitis B virus in chronically infected children after seroconversion from HBsAg to anti-HBs indicating viral persistence. J Hepatol 1997;27:973-8.

3. Kato J., Hasegawa K., Torii N., et al. A molecular analysis of viral persistence in surface-antigen negative chronic hepatitis B. Hepatology 1996;23:389-95.

4. Zhang Y-Y., Hansson B.G., Kuo L.S, et al. Hepatitis B virus in serum and liver is commonly found in Chinese patients with chronic liver disease despite the presence of antibodies to HBsAg. Hepatology 1993;17:538-44.

5. CDC. Hepatitis B virus: a comprehensive strategy for limiting transmission in the United States through universal childhood vaccination. Recommendations of the Immunization Practices Advisory Committee (ACIP). MMWR 1991;40:RR-13:1-25.

6. Lok A.S.F.,McMahon B.J. Chronic hepatitis B. Hepatology 2001;34:1225-41.

7. McQuillan G.M., Townsend T.R., Fields H.A., et al. Seroepidemiology of hepatitis B virus infection in the United States. Am J Med 1989;87(suppl 3A):5S-10S.

8. Bréchot C., Thiers V., Kremsdorf D., et al.. Persistent hepatitis $\mathrm{B}$ virus infection in subjects without hepatitis B surface antigen: Clinically significant or purely “occult". Hepatology 2001;34:194-203.
9. Grob P., Jilg W., Bornhak H., et al.. Serological pattern "anti-HBc alone": report on a workshop. J Med Virol 2000;62:450-5.

10. Loriot M-A., Marcellin P., Walker F., et al. Persistence of hepatitis B virus DNA in serum and liver from patients with chronic hepatitis B after loss of HBsAg. J Hepatol 1997;27:251-8.

11. Cacciola I., Pollicino T., Squadrito G., et al. Occult hepatitis $B$ virus infection in patients with chronic hepatitis $C$ liver disease. N Engl J Med 1999;341:22-6.

12. $\mathrm{Hu}$ K.Q. Occult hepatitis B virus infection and its clinical implications. J Viral Hepat 2002;9:243-57.

13. Fukuda R., Ishimura N., Hamamoto S., et al. Co-infection by serologically-silent hepatitis B virus may contribute to poor interferon response in patients with chronic hepatitis $\mathrm{C}$ by down-regulation of type-I interferon receptor gene expression in the liver. J Med Virol 2001;63:220-7.

14. Gonzalez S, Navas S., Madejon A., et al.. Hepatitis B virus and $\mathrm{D}$ virus genomes in hepatitis $\mathrm{B}$ surface antigen negative patients with chronic hepatitis C. J Med Virol 1995;45:168-73.

15. Koike K., Kobayashi M., Gondo M., et al. Hepatitis B virus DNA is frequently found in liver biopsy samples from hepatitis $\mathrm{C}$ virus-infected chronic hepatitis patients. J Med Virol 1998;54:249-55.

16. Uchida T., Kaneita Y., Gotoh K., et al. Hepatitis C virus is frequently coinfected with serum markernegative hepatitis $B$ virus: probable replication promotion of the former by the latter as demonstrated by in vitro cotransfection. J Med Virol 1997;52:399-405.

17. Villa E., Grottolia A., Buttafoco P., et al. Evidence for hepatitis $\mathrm{B}$ virus infection in patients with chronic hepatitis $\mathrm{C}$ with and without serological markers of hepatitis B. Dig Dis Sci 1995;40:8-11.

18. Zignego A.L., Fontana R., Pulti S., et al. Relevance of inapparent coinfection by hepatitis $\mathrm{B}$ virus in a interferon-treated patients with hepatitis $\mathrm{C}$ virus chronic infection. J Med Virol 1997;51:313-8.

19. Huo T.I., Wu J.C., Lee P.C., et al. Sero-clearance of hepatitis B surface antigen in chronic carriers does not necessarily imply a good prognosis. Hepatology 1998;28:231-6.

20. Paterlini P., Driss F., Nalpas B., et al. Persistence of hepatitis $\mathrm{B}$ and $\mathrm{C}$ viral genomes in primary liver cancers from HBsAg-negative patients: a study of a lowendemic area. Hepatology 1993; 17:20-9.

21. Paterlini P., Poussin K., Kew M., et al. Selective accumulation of the $\mathrm{X}$ transcript of hepatitis $\mathrm{B}$ virus in patients negative for hepatitis B surface antigen with hepatocellular carcinoma. Hepatology 1995;21:313-21. 
22. Sheu J. C., Huang G.T., Shih L.N., et al. Hepatitis C and B viruses in hepatitis B surface antigen-negative hepatocellular carcinoma. Gastroenterology 1992;103:1322-7.

23. Gonçales Jr, F. L., Pereira J. S. F., Silva C., et al.. Hepatitis $B$ virus in sera of blood donors and of patients infected with hepatitis $\mathrm{C}$ virus and human immunodeficiency virus. Clin Diag Lab Immunol 2003; 10:718-20.

24. METAVIR Cooperative Group. Inter-and intra-observer variation in the assessment of liver biopsy of chronic hepatitis C. Hepatology 1994;20:15-20.

25. Poynard T., Bedossa P., Opolon P. Natural history of liver fibrosis progression in patients with chronic hepatitis C. The OBSVIRC, METAVIR, CLINIVIR, and DOSVIR groups. Lancet 1997;349:825-32.

26. Kaneko, S., Feinstone S. M., Miller R.H. Rapid and sensitive method for the detection of serum hepatitis $B$ virus DNA using the polymerase chain reaction technique. J Clin Microbiol 1989;27:1930-3.

27. Kaneko S., Miller R.H., Bisceglie A.M., et al. Detection of hepatitis B virus DNA in serum by polymerase chain reaction. Application for clinical diagnosis. Gastroenterology 1990;99:799-804.

28. Kwok S., Higuchi R. Avoiding false positives with PCR. Nature 1989;339:237-8.

29. Siegel S., Castellan Jr, N.J. Non parametric statistics for the behavioral sciences. New York: McGraw-Hill, 1998.

30. Ackerman Z., Wands J.R, Gazitt Y., et al.. Enhancement of HBsAg detection in serum of patients with chronic liver disease following removal of circulating immune complex. J Hepatol 1994;20:398-404.

31. Liang T.J., Blum H.E., Wands J.R. Characterization and biological properties of a hepatitis B virus isolated from patients without hepatitis virus serologic markers. Hepatology 1990;12:204-12.

32. Mason A.L., Xu L., Linsheng G., et al. P. Molecular basis for persistent hepatitis $B$ virus infection in the liver after clearance of serum hepatitis B surface antigen. Hepatology 1998;27:1736-42.

33. Jeantet D., Chemin I., Mandrand B., et al. Characterization of two hepatitis B virus populations isolated from a hepatitis B surface antigen-negative patient. Hepatology 2002;35:1215-24.

34. Ohkawa K., Hayashi N., Yuki N., et al.. Long-term followup of hepatitis $B$ virus and hepatitis $C$ virus replicative levels in chronic hepatitis coinfected with both viruses. J Med Virol 1995;46:258-64.

35. Sagnelli E., Coppola N., Scolastico C., et al. Virologic and clinical expression of reciprocal inhibitory effect of hepatitis B, C, and delta viruses in patients with chronic hepatitis. Hepatology 2000;32:1106-10.

36. Thiers V., Nakajima E.,. Kremsdorf D., et al. Transmission of hepatitis B from hepatitis-B-seronegative subjects. Lancet 1988; 2:1273-6.
37. Zarski J-P., Bohn B., Bastie A., et al. Characteristics of patients with dual infection by hepatitis $B$ and $C$ viruses. J Hepatol 1998;28:27-33.

38. Bortolotti F., Jara P., Crivellaro C., et al. Outcome of chronic hepatitis B in Caucasian children during a 20-year observation period. J Hepatol 1998;29:184-90.

39. Chan H.L.Y., Leung N.W.Y., Hussain M., et al. Hepatitis B e antigen-negative chronic hepatitis B in Hong-Kong. Hepatology 2000;31:763-8.

40. Chemin I., Jeantet D., Kay A., Trepo C. Role of silent hepatitis virus in chronic hepatitis B surface antigen () liver disease. Antiviral Res 2001;52:117-23.

41. Hadziyannis S. J. Hepatitis B e antigen negative chronic hepatitis B: from clinical recognition to pathogenesis and treatment. Viral Hepat Ver1995; 1:7-36.

42. Pontisso P., Gerotto M., Ruvoletto M.G., et al.. Hepatitis C genotypes in patients with dual hepatitis $\mathrm{B}$ and $\mathrm{C}$ virus infection. J Med Virol 1996;48:157-60.

43. Wang Y.M., Chit W., Lok A.S.F. Suppression of hepatitis $\mathrm{C}$ virus by hepatitis $\mathrm{B}$ virus in coinfected patients at the National University Hospital of Singapore. J Gastroenterol 1999;34:481-5.

44. Ogata N., Zanetti A.R., Yu M., et al. Infectivity and pathogenicity in chimpanzees of a surface gene mutant of hepatitis B virus that emerged in a vaccinated infant. J Infect Dis 1997; 175:511-23.

45. Fukuda R., Ishimura N., Niigaki M., et al. Serologically silent hepatitis $\mathrm{B}$ virus coinfection in patients with hepatitis $\mathrm{C}$ virus associated chronic liver disease: clinical and virological significance. J Med Virol 1999;58:201-7.

46. Giannini E., Ceppa P., Botta F., et al. Previous hepatitis B virus infection is associated with worse disease stage and occult hepatitis B virus infection has low prevalence and pathogenicity in hepatitis $\mathrm{C}$ virus positive patients. Liver Int 2003;23:12-8.

47. Kao J-H, Chen P-J., Lai M-Y., Chen D-S. Occult HBV infection and clinical outcomes of patients with chronic hepatitis C. J Clin Microbiol 2002;40:4068-71.

48. Nerei K., Kaneko M., Moriyama M., Arakama Y. The clinical features of chronic hepatitis $\mathrm{C}$ are not affected by the coexistence of hepatitis B virus DNA patients negative for hepatitis B surface antigen. Intervirology 2000;43:95-101. 